DEVELOPING AN EXPERIMENTAL 方法の開発と接合部内にせん断 TECHNIQUE FOR EXTERIOR BEAM補強筋がない RC 架構への適用

COLUMN JOINTS USING PARTIAL SPECIMENS AND ITS APPLICATION TO LABORATORY TESTS OF R/C JOINTS WITHOUT CONCRETE CONFINEMENT

$\begin{array}{ll}\text { 朝長拓也 }-* 1 & \text { 真田靖士 } \\ \text { 渡邊泰宏— }-2\end{array}$

キーワード :

構造実験，ト形接合部，ロングスパン梁，途上国建築，性能評価

Keywords:

Structural test, Exterior beam-column joint, Long span beam, Buildings in developing countries, Performance evaluation

1.はじめに

近年，世界各地でマグニチュード 7.0 以上の大規模な地震が多発 している。特に, 途上国における被害は甚大で，人命に関わる建築 物の倒壊被害が多数報告されている。2009 年のインドネシア・スマ トラ島西部地震では，いわゆるエンジニアド建築を含む比較的規模 が大きい鉄筋コンクリート造（以下 $\mathrm{RC} ）$ 建物が，極めて甚大な被 害を被った。建物崩壊の主要な原因の 1 つは柱梁接合部にせん断補 強筋が配されていないなどの不適切な構造詳細にあると判断された 1)。また，筆者らによる既往の研究 ${ }^{2)}$ において，代表的な被害事例を 模擬した柱梁接合部の小型模型実験が行われ，被害をおよそ再現で きることが確認された。しかし，小型模型のため，詳細な接合部挙 動の分析には至っていない。

ところで, 一般に柱梁接合部の部分架構実験を行う場合, 柱, 梁 反曲点位置までがモデル化される。そのため，ロングスパン梁を有 する架構では，実験装置の寸法制限により試験体の縮小が必要とな る。その一方で，より実現象に近い実験データを得るためには，実 大に近い試験体を用いて実験を行う必要がある。

以上を背景として, 本研究では, 接合部内にせん断補強筋が配さ れていない RC 外柱一梁部分架構の地震時挙動や性能を解明するこ とを目的として，1）新しい部分架構実験法を提案・検証するとと もに，2）提案した実験法をインドネシアの RC 実被害建物の部分 架構試験体へ適用しその性能評価を行った。
Takuya TOMONAGA - $* 1$

Yasushi SANADA - $* 2$ Yasuhiro WATANABE $-* 1$

An experimental technique using short beam-exterior column joint specimens was proposed to overcome a size limitation of the experimental equipment. Realistic moment distributions were simulated by applying additional moments to the ends of short beams. As a result of the verification test with a steel specimen, it was confirmed that curvature and axial strain distributions were consistent with theoretical estimations. Application tests of the proposed experimental system were conducted using two $3 / 4$ scale R/C beam-column joint specimens representing an earthquake-damaged joint in developing countries. Seismic behavior of the joints was observed and represented by an asymmetric rocking model.

\title{
2. 外柱一梁接合部の部分架構実験法の開発
}

提案する方法は, 外柱一梁接合部の部分架構の中で一般に寸法が 長い梁を短スパン化し, 梁端に付加モーメントを作用させることで 実建物と同様のモーメント分布を実現する実験方法である。図 1 (a)

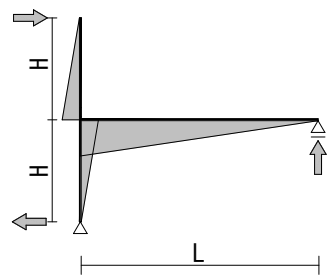

（a）地震時モーメント分布

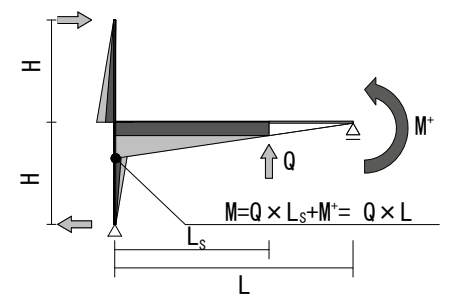

(b) 付加モーメントによる再現 図 1 外柱一梁接合部の部分架構の実験計画

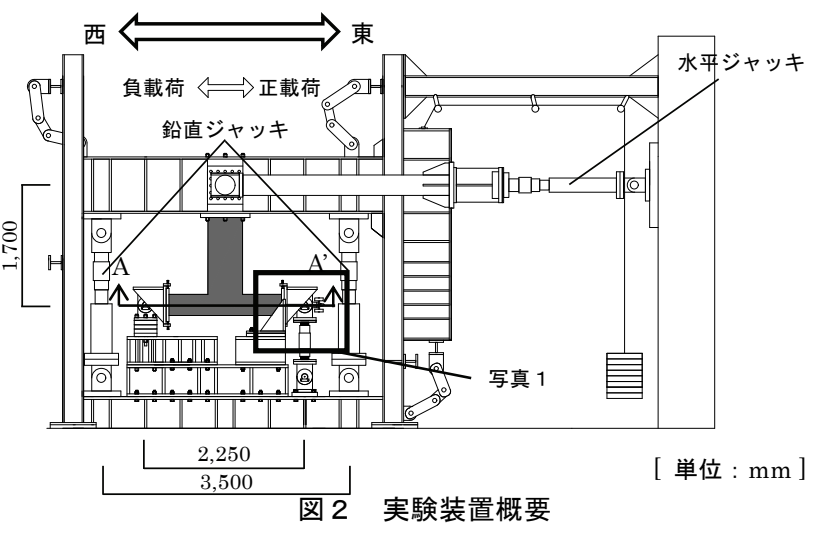

豊橋技術科学大学大学院工学研究科 大学院生

( T 441-8580 愛知県豊橋市天伯町雲雀ヶ丘 1-1)

大阪大学大学院工学研究科 准教授・博士 (工学)

大阪大学大学院工学研究科 大学院生
Graduate Student, Graduate School of Engineering, Toyohashi Univ. of Technology

Assoc. Prof., Graduate School of Engineering, Osaka Univ., Dr. Eng. Graduate Student, Graduate School of Engineering, Osaka Univ. 


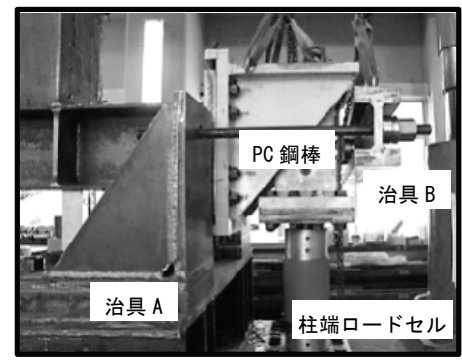

写真 1 軸力導入装置

に外柱一梁接合部の典型的な地震時のモーメント分布を示す。これ を維持した状態で梁を短スパン化するため, 同図(b)のように, 付加 モーメント $\mathrm{M}^{+}$を短スパン化した梁端へ作用させる計画とした。

図 2 に上記の実験方法を実現するための実験装置の計画を示す。 試験体は同図に示寸ように架構を $90^{\circ}$ 回転させて実験装置に設置し, 東西の鉛直ジャッキにより試験体梁端に付加モーメントを作用させ る。柱への軸力の導入は, 写真 1 （図 2 参照）に示寸軸力導入用治 具と PC 鋼棒を用いて行った。図 3 に実験装置脚部の概念図, 図 4 に軸力導入方法の概念図を図 2 の A-A'断面図を用いて示す。実験装 置基部に固定した治具 $\mathrm{A}$ と東側のローラー頭部（図 $2 \sim 4$, 写真 1 参照）と接続した治具 $\mathrm{B}$ を, $\mathrm{PC}$ 鋼棒を用いて結び, $\mathrm{PC}$ 鋼棒へ緊張 力を導入することで，柱へ軸力を導入する計画とした。

なお，試験体への水平載荷および柱への軸力導入に伴う東側の口 ーラーの微小な傾きを吸収するため, 治具 $\mathrm{A} \sim \mathrm{PC}$ 鋼棒間, 治具 $\mathrm{B}$ 〜 PC 鋼棒間, 治具 B〜東側ローラー間は，それぞれ球座を用いて接 続した (図 4 参照)。

\section{3. 検証実験}

\section{1 外柱一梁接合部の鉄骨造試験体}

検証実験に用いる鉄骨造試験体は，文献 2)の研究対象接合部を基 に計画した。写真 2 に示すように, 研究対象接合部は接合部内にせ 儿断補強筋が配されておらず，損傷が接合部に集中した実地震被害 事例である。図 5 に研究対象接合部の柱, 梁内法スパン中央までの 外形および柱・梁断面図を示す。鉄骨造試験体は, 研究対象接合部 の縮尺およそ $3 / 4$ の模型であり, 上下の柱長さの $1 / 2$, 梁の端部から 長さ $1.09 \mathrm{~m}$ (2D 以上, D : 梁せい) を切り出した部分架構である。 図 6 に鉄骨造試験体形状を, 表 1 に鉄骨造試験体構造諸元と, 使用 した鉄骨の材料試験結果を併せて示す。

\section{2 載荷計画と計測計画}

試験体は，下階柱端（図 2 中，西柱端）にピン支承，上階柱端（図 2 中，東柱端）にローラー支承を接続して載荷装置へ固定した。柱 に入力されるせん断力を測定するため, 東柱端のローラー支承内に 鋁直方向にロードセルを設置した。梁端は加力梁と固定した。載荷 は, 柱への一定軸力載荷下で, 図 2 中の水平ジャッキの荷重制御に より水平方向への静的正負繰り返し荷重を与えた。なお，本実験で は東側（図２）への載荷を正載荷, 西側への載荷を負載荷としてい る。導入軸力は, 文献 2)上り研究対象接合部の負担軸力を算出, 縮 尺し $250 \mathrm{kN}$ とした。導入軸力の制御は, 図 4 中に匹で示す, PC 鋼棒 に貼付したひずみゲージによって計測ステップ毎に行った。対象建 物の実際の梁長さを想定したモーメント分布を実現する付加モーメ ント $\mathrm{M}^{+}$を導入するため, 式(1)（図 1，2，5参照）により東西ジ

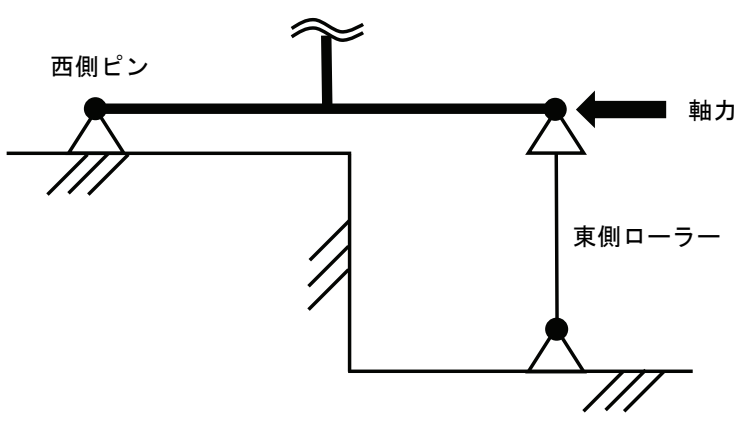

図 3 実験装置脚部の概念図

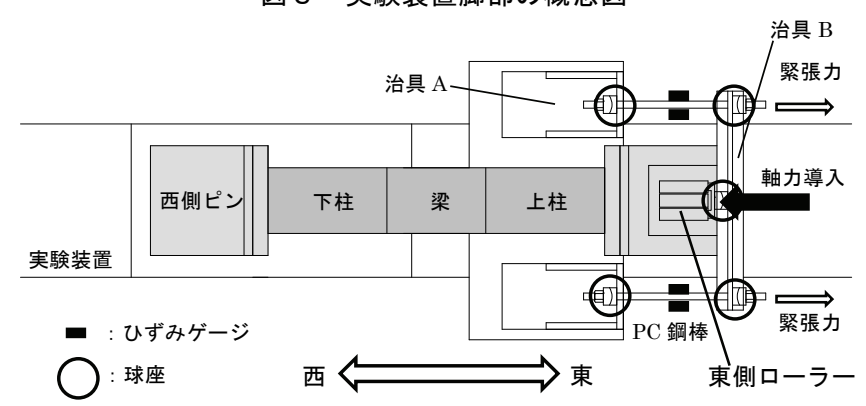

図 4 軸力導入方法の概念図

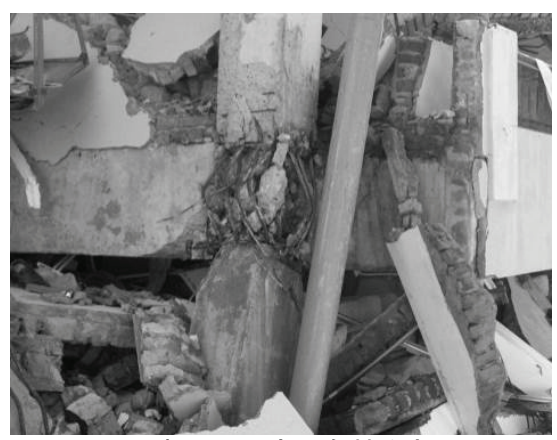

写真 2 研究対象接合部

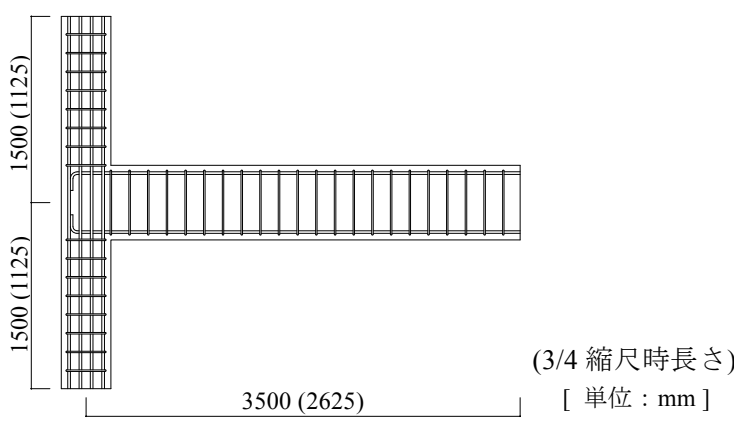

(a) 研究対象接合部外形（内法スパン中央までを示す）

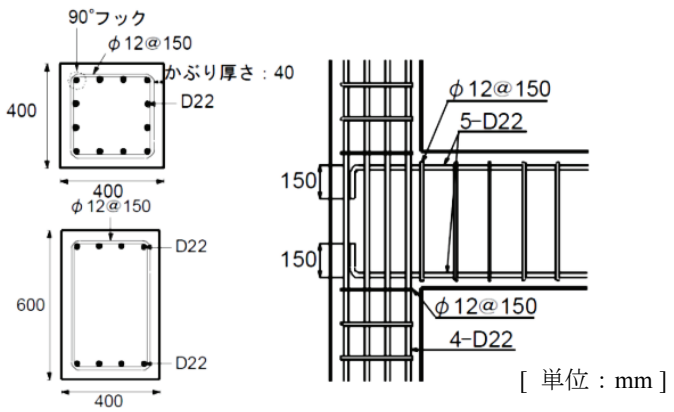

(b) 研究対象接合部 柱·梁断面図

図 5 研究対象建物の柱梁接合部 
ヤッキのカを求めた。

$$
N= \pm \frac{\left(L-L_{S}\right)}{L_{J}} \times P= \pm \frac{(2,625-1,700)}{3,500} \times P
$$

ここで, $N$ : 東西鈶直ジャッキの目標軸力, $L$ : 想定する梁長さ, $L_{S}$ : 短スパン化した梁長さ, $L_{J}$ : 東西鉛直ジャッキ間の距離, $P$ : 水 平ジャッキの水平力である。

載荷プログラムは, 水平力 $\pm 50 \mathrm{kN}$ および士 $100 \mathrm{kN}$ までをそれぞれ 1 サイクルとした。また, 試験体の各部材の上下フランジに, 図 6 中の・で示す位置に， $100 \mathrm{~mm}$ 間隔でひずみゲージを 2 列貼付し，ひ ずみ度の計測を行った。

\section{3 検証結果}

図 7 に, 水平力 $100 \mathrm{kN}$ 載荷時におけるひずみゲージより計測され た架構の曲率分布および柱のひずみ度分布を, それぞれ導入水平力

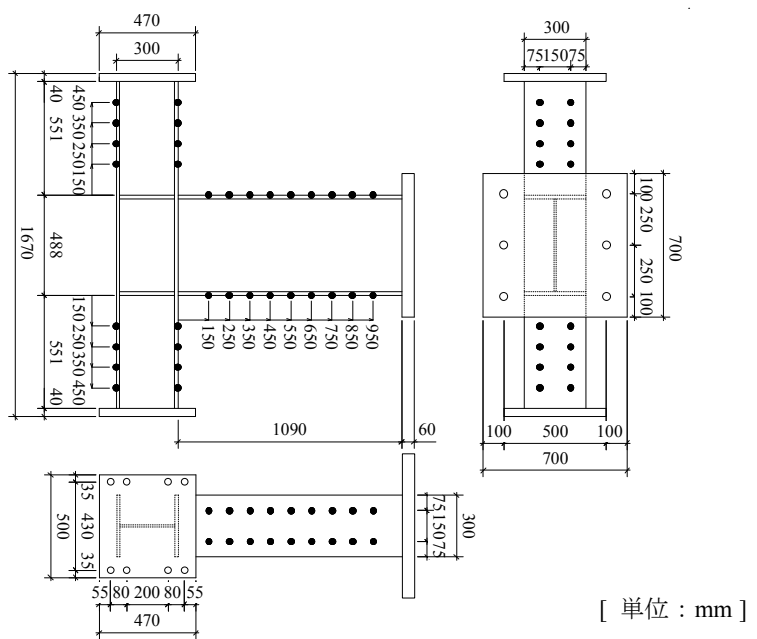

図 6 鉄骨造試験体形状

表 1 鉄骨造試験体構造諸元

\begin{tabular}{c|c|c}
\hline 部位 & 柱 & 梁 \\
\hline 断面 $(\mathrm{mm})$ & $\mathrm{H}-300 \times 300 \times 10 \times 15$ & $\mathrm{H}-488 \times 300 \times 11 \times 18$ \\
\hline 種別 & $\mathrm{SS} 400$ & $\mathrm{SS} 400$ \\
\hline 弾性係数 $\left(\mathrm{N} / \mathrm{mm}^{2}\right)$ & $2.14 \times 10^{5}$ & $2.06 \times 10^{5}$ \\
\hline 降伏応力 $\left(\mathrm{N} / \mathrm{mm}^{2}\right)$ & 272 & 310 \\
\hline 引張応力 $\left(\mathrm{N} / \mathrm{mm}^{2}\right)$ & 437 & 430 \\
\hline 降伏ひずみ $(\mu)$ & 2080 & 2102 \\
\hline
\end{tabular}

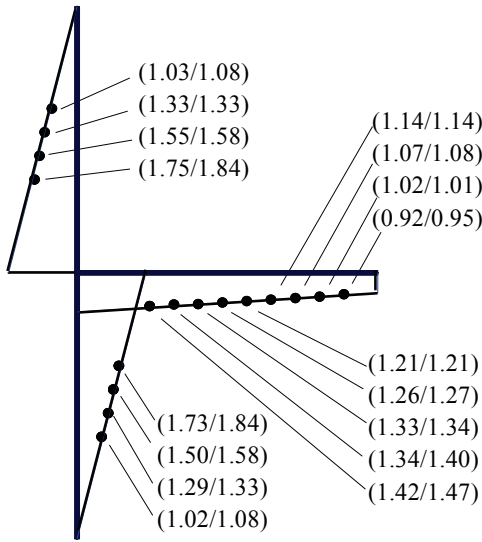

(a) 曲率分布 $(\mu / \mathrm{mm})$

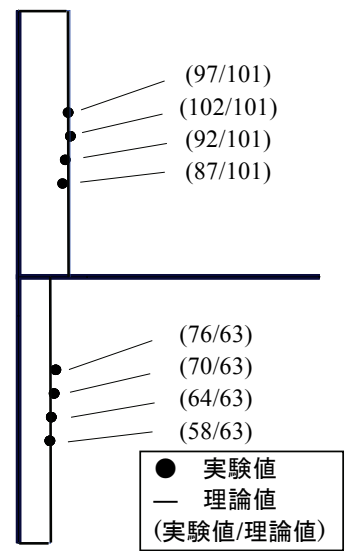

(b) ひずみ度分布 $(\mu)$
図 7 検証結果
および軸力から算出した理論值と比較して示す。曲率とひずみ度の 実験值は，フランジに貼付したひずみゲージ 2 枚の平均值である。 なお，変動軸力が作用する下階柱（図 2 中, 西柱）のひずタ度の理 論值は, 以下の式(2)より求めた。

$$
L^{\varepsilon} N=(N-P) /\left(A_{C} \times E_{S C}\right)
$$

ここで, ${ }_{L} \varepsilon_{N}$ : 下階柱のひずみ度, $N$ : 柱への導入軸力, $P$ : 梁の せん断力（図 2 中，東方向への載荷が正), $A_{C}$ : 柱断面積, $E_{S C}$ : 柱 鉄骨のヤング係数である。

図 7 より，全部材の曲率および柱部材のひずみ度の計測值と理論 值が良好に整合しており，本実験方法により短スパン化した試験体 へ，適切な載荷が可能であることを検証した。

\section{RC 外柱一梁接合部の性能評価実験への適用}

\section{1 接合部にせん断補強筋がない外柱一梁部分架構の RC 試験体}

$\mathrm{RC}$ 試験体は，前章で示した鉄骨造試験体と同様に，文献 2)の研 究対象接合部（図 5 ) を参考に, 縮尺が $3 / 4$ となるように計画した。 表 2 に RC 試験体構造諸元, 図 8 に RC 試験体形状, 表 3 に使用し たコンクリートおよび鉄筋の材料試験結果をそれぞれ示す。柱部材 への導入軸力の有無をパラメータとして, 軸力なし試験体 $\mathrm{J} 1$ と軸力 あり試験体 $\mathrm{J} 1 \mathrm{~N}$ の計 2 体を計画した。RC 試験体は図 5 に示した研 究対象接合部を模擬し配筋したため，接合部内にせん断補強筋が配 されておらず，柱梁の補強筋の端部が $90 \circ$ フッグあるなど構造詳 細が不適切である。
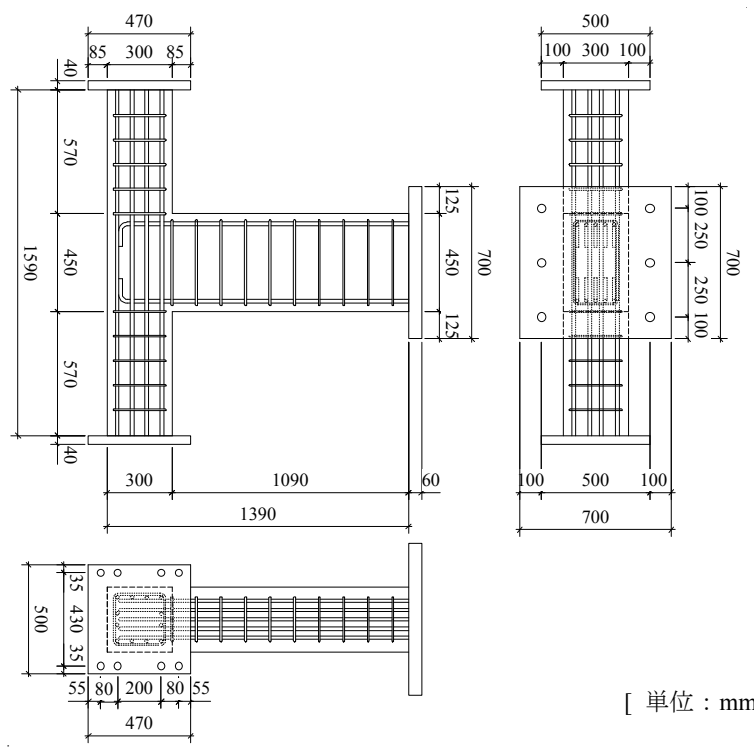

（a） RC 試験体外形

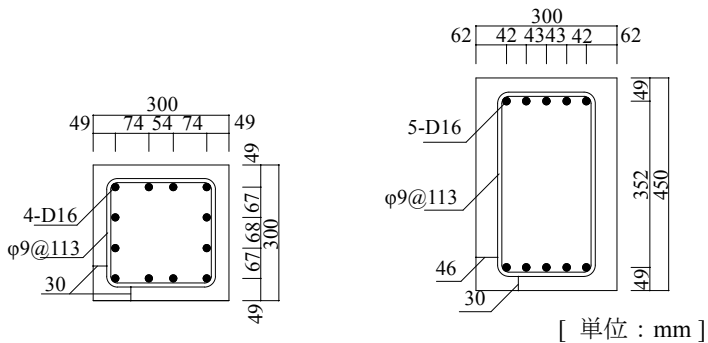

(b) RC 試験体 柱 · 梁断面図

図 $8 \mathrm{RC}$ 試験体形状 
表 $2 \mathrm{RC}$ 試験体構造諸元

\begin{tabular}{c|c|c}
\hline 部位 & 柱 & 梁 \\
\hline 断面 & $300 \times 300 \mathrm{~mm}$ & $300 \times 450 \mathrm{~mm}$ \\
\hline 主筋 & $4-\mathrm{D} 16\left(\mathrm{p}_{\mathrm{t}}=0.88 \%\right)$ & $5-\mathrm{D} 16\left(\mathrm{p}_{\mathrm{t}}=0.74 \%\right)$ \\
\hline 補強筋 & \multicolumn{2}{|c}{$\phi 9-113 \mathrm{~mm}\left(\mathrm{p}_{\mathrm{w}}=0.38 \%\right)$} \\
\hline \multirow{2}{*}{ ここで, $\mathrm{p}_{\mathrm{t}}:$ 引張鉄筋比, $\mathrm{p}_{\mathrm{w}}:$ せん断補強筋比 } \\
表 3 材料特性
\end{tabular}

表 3 材料特性

\begin{tabular}{|c|c|c|c|c|c|c|c|}
\hline \multicolumn{4}{|c|}{ コンクリート } & \multicolumn{4}{|c|}{ 鉄筋 } \\
\hline \multirow{2}{*}{ 試験体 } & $E_{c}$ & $\sigma_{\mathrm{B}}$ & $\sigma_{\mathrm{t}}$ & \multirow{2}{*}{ 種別 } & $E_{s}$ & $f_{y}$ & $\varepsilon_{\mathrm{y}}$ \\
\hline & \multicolumn{3}{|c|}{$\mathrm{N} / \mathrm{mm}^{2}$} & & \multicolumn{2}{|c|}{$\mathrm{N} / \mathrm{mm}^{2}$} & $\mu$ \\
\hline $\mathrm{J} 1$ & $2.41 \times 10^{4}$ & 19.5 & 3.0 & D16 & $1.86 \times 10^{5}$ & 383 & 2063 \\
\hline J1N & $2.08 \times 10^{4}$ & 18.9 & 3.0 & $\phi 9$ & $2.06 \times 10^{5}$ & 370 & 1758 \\
\hline
\end{tabular}

※ 対象建物のコンクリート圧縮強度は $21\left(\mathrm{~N} / \mathrm{mm}^{2}\right)$

※ 対象建物の鉄筋(D22， $\phi 12)$ の降伏強度はそれぞれ $392 ， 326\left(\mathrm{~N} / \mathrm{mm}^{2}\right)$

\section{2 載荷方法と計測方法}

載荷は，3 章の検証実験と同様に，柱の軸力を一定に保った状態 での水平ジャッキ(図 2 )による静的正負交番繰り返し載荷である。 ただし, 梁の変形角（後述の図 10 中, 制御変位/梁長さにより算定） によって載荷を制御した。RC 試験体の実験においても，東側（図 2 ) への載荷を正載荷とした。導入軸力は $\mathrm{J} 1$ が $0 \mathrm{kN}, \mathrm{J} 1 \mathrm{~N}$ が $250 \mathrm{kN}$ である（ただし，両試験体の下階柱には梁の変動軸力が作用する）。 $\mathrm{J} 1 \mathrm{~N}$ の導入軸力は鉄骨造試験体同様，研究対象接合部の作用軸力を 縮尺して算定した。写真 3 にC 試験体の設置状況を示す。

正負交番載荷プログラムは，図 9 に示すように変形角（以下，R） $\mathrm{R}=1 / 800 ， 1 / 400 ， 1 / 200 ， 1 / 133 ， 1 / 100 ， 1 / 67,1 / 50,1 / 33,1 / 25 \mathrm{rad}$. をそれぞれ 1 サイクル行い, 最後に $\mathrm{R}=1 / 17 \mathrm{rad}$ まで正方向に半サイ クルとした。
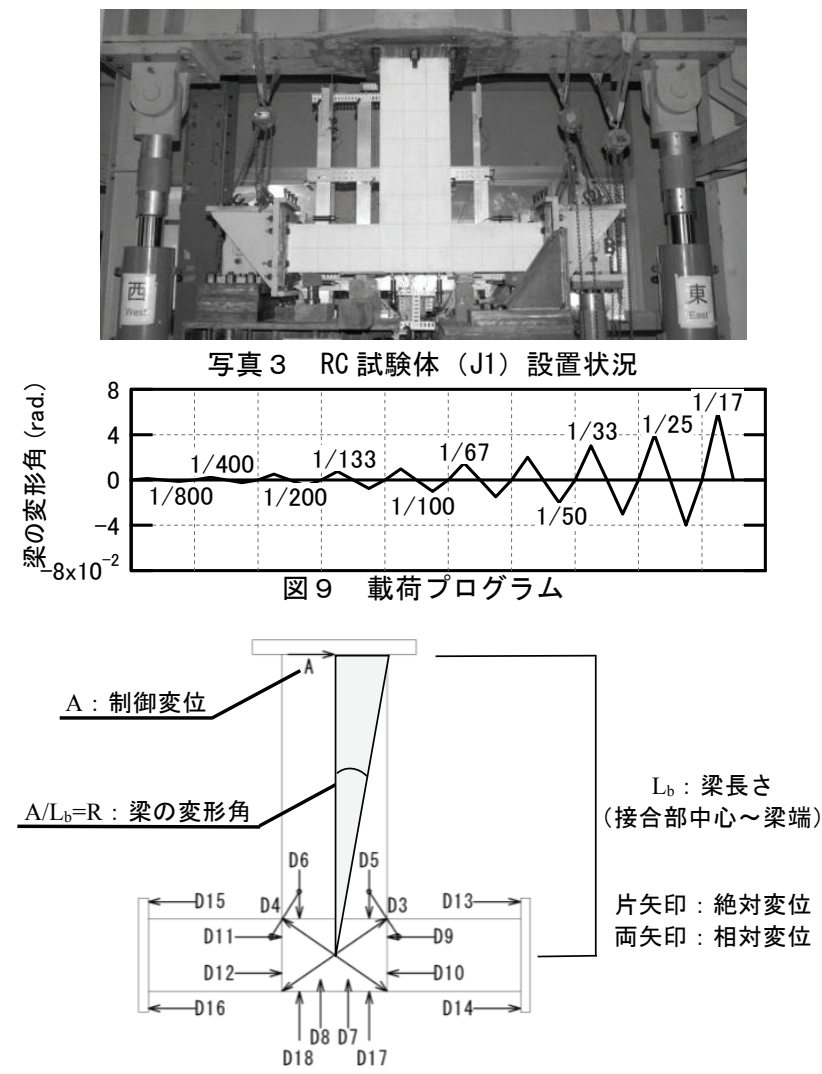

図 10 変位計測位置および制御変位（制御変形角）
図 10 に変位計測位置, 図 11 に接合部内ひずみゲージ貼付位置 を示す。接合部内のひずみゲージは文献 2)より，せん断ひび割れの 発生位置を図 11 の破線（接合部入隅と梁主筋折り曲げ部中央を結 ぶ直線）の通り予想し，その予想線に基づいて貼付位置を決定した。

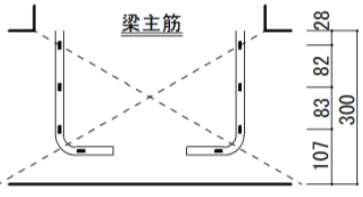

$\lfloor 63 \mid \quad\lfloor 63 \mid$

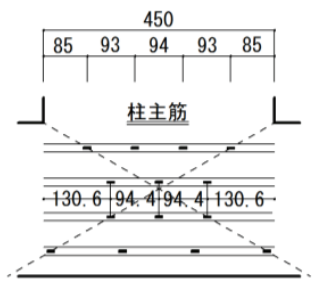

14.3|| $140|141.4| 140|| 14.3$
図 11 接合部内ひずみゲージ貼付位置

\section{3 実験結果}

図 12 に各試験体の接合部モーメントと梁の変形角の関係をそれ ぞれ示す。接合部モーメントは柱端ロードセルにより計測したせん 断力と柱両端のピン, ローラー中心間距離の積として求めた。写真 4，5 亿軸力なし試験体 J1 が最大耐力を記録した 1/67 サイクル正 側ピーク時, 実験終了時の両試験体の破壊状況を比較して示す。

両試験体ともに $\mathrm{R}=1 / 800$ のサイクルで接合部の引張側入隅部や梁 の引張側側面に初期曲げひび割れが発生した。柱の初期曲げひび割 れは，J1 では $\mathrm{R}=1 / 800 ， \mathrm{~J} 1 \mathrm{~N}$ では $\mathrm{R}=1 / 200$ で観測された。 $\mathrm{R}=1 / 200$ で接合部に対角方向のせん断ひび割れが発生し，これらのひび割れ は柱の外側主筋に沿って進展した（写真 4 ）。また，接合部せん断ひ び割れ後に試験体の剛性が著しく低下した。J1 では $\mathrm{R}=1 / 100 ， \mathrm{~J} 1 \mathrm{~N}$ では $\mathrm{R}=1 / 67$ のサイクルより接合部せん断ひび割れ上でカバーコン クリートの剥離が生じ始めた。 $\mathrm{J} 1$ では $\mathrm{R}= \pm 1 / 67, \mathrm{~J} 1 \mathrm{~N}$ では $\mathrm{R}=1 / 67$, -1/100 のサイクルでそれぞれ正負最大耐力に達し, 耐力が緩やかに 低下した。両試験体ともに最大耐力まで，柱，梁主筋は降伏しなか

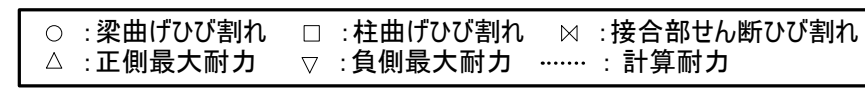
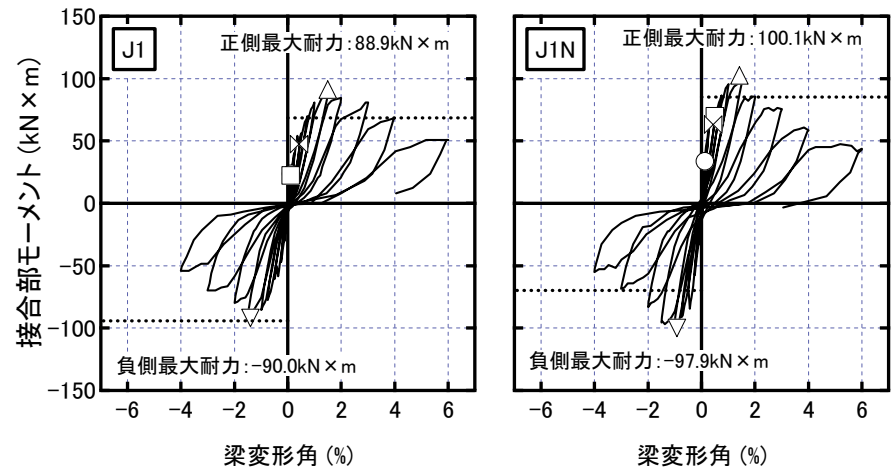

図 12 荷重変形関係
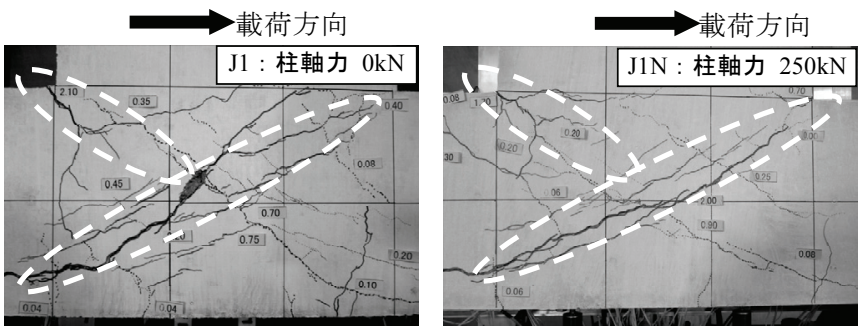

写真 $4 \quad 1 / 67$ サイクル正側ピーク時 接合部破壊状況 


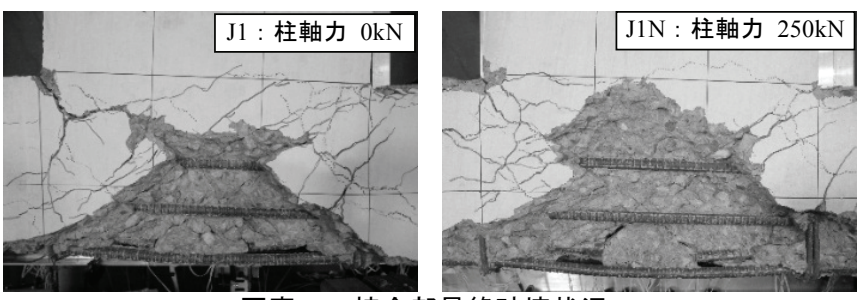

写真 5 接合部最終破壊状況

ったため, 接合部耐力により架構の耐力が上限に達したと判断され る。 $\mathrm{R}=1 / 25$ で, 両試験体ともに柱主筋が露出し, 座屈が確認された。 また, 写真 5 に示すように, 柱主筋に沿い進展した接合部せん断ひ び割れが柱の外面に貫通し, 接合部コンクリートが大きく剥落した。 $\mathrm{R}=1 / 17$ まで正方向に半サイクル載荷し，実験終了とした。

\section{5. 接合部のせん断挙動}

\section{1 接合部の変形モデル}

一般に普及している構造設計や構造解析では接合部は平行四辺形 状に変形すると仮定されている。しかし, RC 試験体の破壊状況（写 真 4 ）から，接合部のせん断変形は一様ではなく，同写真に示すよ うな接合部の引張側入隅から接合部中央に伸びる斜めひび割れ（入 隅ひび割れ）と，接合部の対角線上のひび割れ（対角ひび割れ）が 開閉する挙動が卓越していた。

そこで本研究では，文献 3)～5) も参考として図 13 に示すような 接合部変形モデル（以下，非対称変形モデル）を推定した。非対称 変形モデルは，上記の接合部入隅ひび割れと対角ひび割れの発生と 拡幅に伴って, 同図のように接合部片側の三角形（引張側入隅部を 頂点, 対角ひび割れを底辺とする三角形）のせん断変形が卓越する 変形モデルである。以下では, 本変形モデルの妥当性を変形と耐力 の実験值に基づいて検証する。

\section{2 変形状態の検証}

図 13 に示寸非対称変形モデルでは，接合部引張側入隅を頂点と する上三角形と，もう一方の下三角形が独立にせん断変形する。そ こで，両せん断変形 $\gamma_{u} ， \gamma_{l}$ を式(3)，(4)により評価し，図 14 にお いて比較する。上三角形のせん断変形 $\gamma_{u}$ が終始卓越し, 例えば両試 験体が正側最大耐力を記録した $\mathrm{R}=1 / 67$ では $\gamma_{u}$ が $\gamma_{l}$ の約 5.5 倍程度 であり，接合部が非対称にせん断変形していることを確認できる。

$$
\begin{aligned}
\gamma_{u} & = \begin{cases}\phi_{u}-\phi_{w} & \text { (正載荷時) } \\
\phi_{u}-\phi_{e} & \text { (負載荷時) }\end{cases} \\
\gamma_{l} & = \begin{cases}\phi_{l}-\phi_{e} & \text { (正載荷時) } \\
\phi_{l}-\phi_{w} & \text { (負載荷時) }\end{cases}
\end{aligned}
$$

ここで， $\phi_{u}$ ：接合部上面の絶対回転量（図 $10 ， \mathrm{D} 5, \mathrm{D} 6$ より計 測), $\phi_{l}$ : 接合部下面の絶対回転量 (図 $10, \mathrm{D} 17, \mathrm{D} 18$ より計測), $\phi_{e}$ : 接合部東面の絶対回転量 (図 $10, \mathrm{D} 9, \mathrm{D} 10$ より計測), $\phi_{w}$ : 接合部西面の絶対回転量（図 $10, \mathrm{D} 11, \mathrm{D} 12$ より計測）である。

\section{3 耐力に関する検証}

文献 3)〜 5)を参考に，図 13 に示した接合部のひび割れ面での力 のつり合いを考え，接合部の抵抗モーメントを算出した。図 15 に 正載荷時の接合部内における鉄筋およびコンクリートの想定応力分 布を示す。同図(b)中に で示すコンクリートの応力重心位置に作用 するモーメントの総和が, 抵抗モーメントに相当し, 眓中の記号を

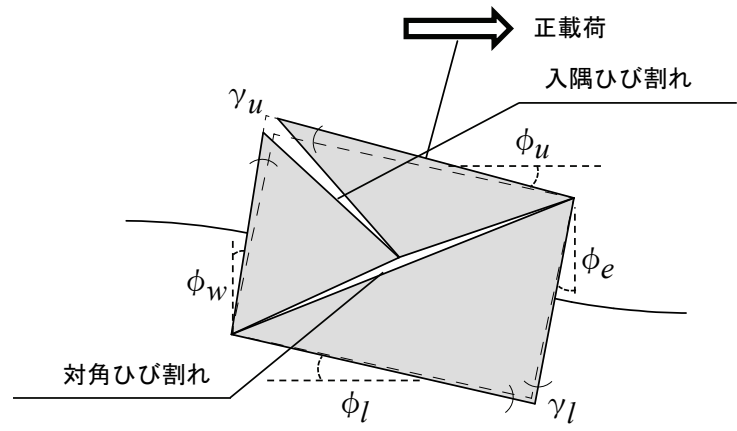

図 13 非対称変形モデル
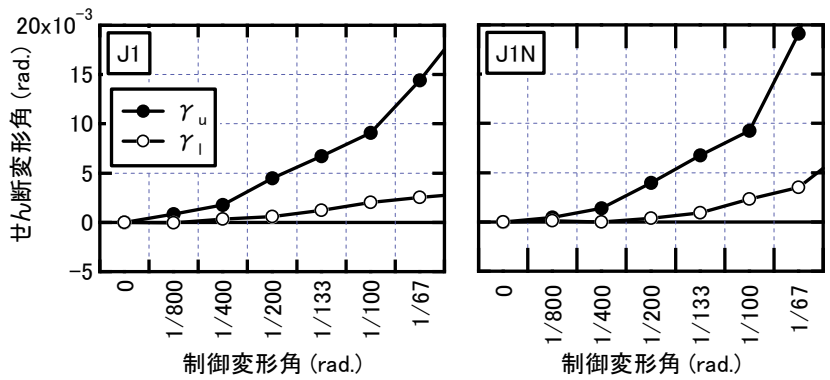

図 14 両せん断変形角の比較（正載荷時）

用いると式(5)のように表される。同式では外力に抵抗するモーメン 卜を正として記述した。なお，算定仮定を以下にまとめる。詳細な 算定過程は付録を参照されたい。

・外力は図中の $\mathrm{O}$ 点に作用し, $\mathrm{O}$ 点を境界とする断面両側にそれぞ れ $1 / 2$ ずつ作用するものと扱う。

・コンクリートは圧縮域において $\beta_{3} \quad(=0.85) \times$ 圧縮強度の大きさ の応力を負担する ${ }^{6}$ 。ここで， $\beta_{3}$ はストレスブロックに置換するた めの強度低減係数である。

本研究では, 前節の $\mathrm{RC}$ 試験体による実験における正負最大耐力 時の鉄筋のひずみ度の実験值を用いて $M_{J}$ を評価し，モデルの妥当 性を検討した。
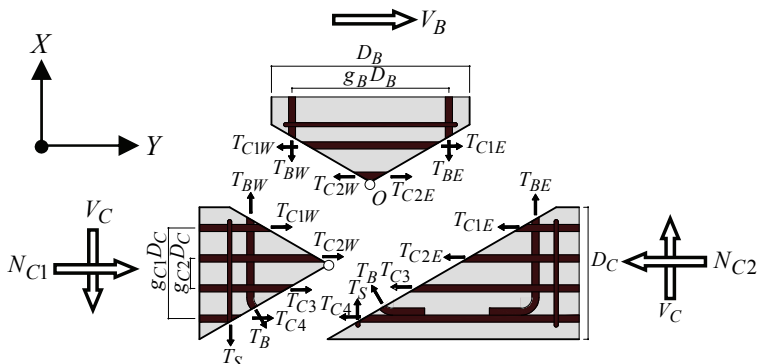

(a) 鉄筋の応力

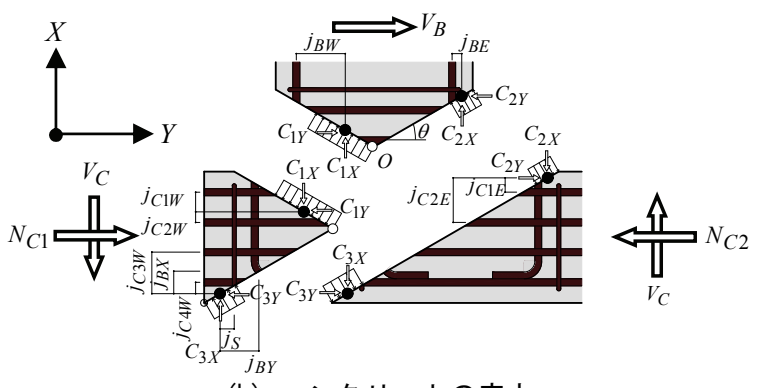

(b) コンクリートの応力

図 15 接合部内の応力状態（正載荷時） 


$$
\begin{aligned}
& M_{J}=T_{B W} \times j_{B W}+T_{B E} \times j_{B E}+T_{C 1 E} \times j_{C 1 E}+T_{C 2 E} \times j_{C 2 E} \\
&+T_{C 1 W} \times j_{C 1 W}-T_{C 2 W} \times j_{C 2 W}+T_{C 3} \times j_{C 3 W}+T_{C 4} \times j_{C 4 W} \\
&+T_{B} \cos 45^{\circ} \times j_{B X}+T_{B} \sin 45^{\circ} \times j_{B Y}+T_{S} \times j_{S} \\
&-\frac{N_{C 1}}{2}\left(\frac{1}{2} \frac{C_{1 Y}}{b \beta_{3} f_{C}}\right)+\frac{N_{C 1}}{2}\left(D_{C}-l_{X 0}-\frac{1}{2} \frac{C_{3 Y}}{b \beta_{3} f_{C}}\right) \\
&+\frac{N_{C 2}}{2}\left(l_{X 0}-\frac{1}{2} \frac{C_{2 Y}}{b \beta_{3} f_{C}}\right)-\frac{N_{C 2}}{2}\left(D_{C}-l_{X 0}-\frac{1}{2} \frac{C_{3 Y}}{b \beta_{3} f_{C}}\right) \\
&+\frac{V_{B}}{2}\left(\frac{1}{2} \frac{C_{1 Y}}{b \beta_{3} f_{C}}\right)+\frac{V_{B}}{2}\left(l_{X 0}-\frac{1}{2} \frac{C_{2 Y}}{b \beta_{3} f_{C}}\right) \\
&+\frac{V_{C}}{2}\left(\frac{1}{2} \frac{C_{1 X}}{b \beta_{3} f_{C}}\right)+\frac{V_{C}}{2}\left(\frac{l_{X 0}}{\tan \theta}-\frac{1}{2} \frac{C_{2 X}}{b \beta_{3} f_{C}}\right)
\end{aligned}
$$

ここで， $M_{J}$ : 接合部抵抗モーメント，その他の記号は図 15 お よび付録を参照されたい。

計算結果を表 4 および図 12 に荷重変形関係と併せて示す。非対 称変形モデルに基づく耐力計算によって, 耐力の実験值をおよそ評 価できることを確認した。

\section{表 4 計算耐力と実験耐力の比較}

\begin{tabular}{c|c|c|c|c}
\hline \multirow{2}{*}{ 試験体 } & 載荷方向 & $\begin{array}{c}\text { 実験值 } \\
(\mathrm{kN} \times \mathrm{m})\end{array}$ & $\begin{array}{c}\text { 計算值 } \\
(\mathrm{kN} \times \mathrm{m})\end{array}$ & 実験值/計算值 \\
\hline \multirow{2}{*}{$\mathrm{J} 1$} & 正 & 88.9 & 68.5 & 1.30 \\
\cline { 2 - 5 } & 負 & -90.0 & -94.2 & 0.96 \\
\hline \multirow{2}{*}{$\mathrm{J} 1 \mathrm{~N}$} & 正 & 100.1 & 85.3 & 1.17 \\
\cline { 2 - 5 } & 負 & -97.9 & -69.7 & 1.40 \\
\hline
\end{tabular}

\section{6. まとめ}

本研究では, 接合部にせん断補強筋がない RC 外柱一梁部分架構 のせん断変形メカニズムを解明することを目的として，1）梁を短 スパン化した実験方法の開発を行い，鉄骨造試験体による構造実験 を通して，開発した実験方法の検証を行った。さらに，2）提案し た実験方法を RC 外柱一梁接合部に適用し, 同接合部の破壊メカニ ズムを実験的に検討した。本研究により得られた知見を以下にまと める。

1. 外柱一梁接合部の部分架構実験において, 梁を短スパン化し, 梁端に付加モーメントを作用することで, 部分架構試験体に実 建物相当のモーメント分布を導入する実験方法を開発した。ま た，同実験方法を鉄骨造試験体に適用した結果，柱梁の曲率と ひず夕度の計測結果が理論值と整合しており, 計画した応力分 布の実現を確認した。

2. 同実験方法を軸力の有無をパラメータとする接合部にせん断 補強筋がない RC 部分架構試験体 2 体に適用し, 構造実験を行 った。その結果，接合部は引張側入隅から中央に伸びるひび割 れ（入隅ひび割れ）と，対角線上のひび割れ（対角ひび割れ） が開閉する挙動が卓越することを確認した。

3.上記の挙動を表現する接合部引張側入隅を頂点とする上三角 形と，もう一方の下三角形が独立にせん断変形する非対称せん 断変形モデルを提示し, 変形と耐力の実験值との比較を通して モデルの妥当性を検証した。接合部のせん断変形はモデルの上 三角形が下三角形より明らかに大きく非対称に変形すること, 同モデルで想定するひび割れ面の力のつり合いに基づき算定 される接合部抵抗モーメントが実験結果の曲げ耐力とおよそ 整合することを確認した。

\section{謝辞}

研究を支援頂いた豊橋技術科学大学佐島悠太氏に謝意を表す。

\section{参考文献}

1）倉本洋，真田靖士，崔琥，坂下雅信，日比野陽，壁谷澤寿一，秋田知芳： 2009 年インドネシア・スマトラ島西部地震の調査速報, 建築雑誌, Vol.125, No.1601, pp.55-62, 2010.3

2）佐島悠太，新田剛士，朝長拓也，真田靖士：途上国の不適切な構造詳細 を有する RC 外柱梁接合部の小型模型実験による性能評価，構造工学論 文集 Vol.58B，pp.41-47，2012.3

3）塩原等：鉄筋コンクリート柱梁接合部：見逃された破壊機構，日本建築 学会構造系論文集，第 73 巻，第 631 号，pp.1641-1648，2008.9

4) 塩原等: 鉄筋コンクリート柱梁接合部: 終局強度と部材端力の相互作用, 日本建築学会構造系論文集, 第 74 巻, 第 635 号, pp.121-128, 2009.1

5）楠原文雄，塩原等：鉄筋コンクリート造十字形柱梁接合部の終局モーメ ント算定法, 日本建築学会構造系論文集, 第 75 巻, 第 657 号, pp.2027-2035, 2010.11

6) American Concrete Institute : Building Code Requirement for Structural Concrete (ACI 318M-11) and Commentary, 2011.10

\section{付録 接合部の抵抗モーメントの算定過程}

\section{ひび割れ面の応力の釣り合い}

$$
\begin{array}{ll}
C_{1 X}=T_{B W}-V_{C} / 2 & C_{1 Y}=T_{C 1 W}+T_{C 2 W}-V_{B} / 2+N_{C 1} / 2 \\
C_{2 X}=T_{B E}+V_{C} / 2 & C_{2 Y}=T_{C 1 E}+T_{C 2 E}+V_{B} / 2+N_{C 2} / 2 \\
C_{3 X}=T_{S}+T_{B} \sin 45^{\circ}+V_{C} / 2 & C_{3 Y}=T_{C 3}+T_{C 4}+T_{B} \cos 45^{\circ}+N_{C 1} / 2
\end{array}
$$

\section{コンクリート応カ重心位置から主筋までの距離の算定}

$$
\begin{array}{ll}
j_{B W}=\frac{g_{B} D_{B}}{2}-\frac{1}{2} \frac{C_{1 X}}{b \beta_{3} f_{C}} & j_{B E}=\frac{\left(1-g_{B}\right) D_{B}}{2}-\frac{1}{2} \frac{C_{2 X}}{b \beta_{3} f_{C}} \\
j_{C 1 W}=l_{X 0}-\frac{1}{2} \frac{C_{1 Y}}{b \beta_{3} f_{C}}-\frac{\left(1-g_{C 1}\right) D_{C}}{2} & j_{C 2 W}=-l_{X 0}+\frac{1}{2} \frac{C_{1 Y}}{b \beta_{3} f_{C}}+\frac{\left(1-g_{C 2}\right) D_{C}}{2} \\
j_{C 3 W}=\frac{\left(1-g_{C 2}\right) D_{C}}{2}-\frac{1}{2} \frac{C_{3 Y}}{b \beta_{3} f_{C}} & j_{C 4 W}=\frac{\left(1-g_{C 1}\right) D_{C}}{2}-\frac{1}{2} \frac{C_{3 Y}}{b \beta_{3} f_{C}} \\
j_{C 1 E}=\frac{\left(1-g_{C 1}\right) D_{C}}{2}-\frac{1}{2} \frac{C_{2 Y}}{b \beta_{3} f_{C}} & j_{C 2 E}=\frac{\left(1-g_{C 2}\right) D_{C}}{2}-\frac{1}{2} \frac{C_{2 Y}}{b \beta_{3} f_{C}} \\
j_{B X}=D_{C}-l_{X 0}-l_{B X}-\frac{1}{2} \frac{C_{3 Y}}{b \beta_{3} f_{C}} & j_{B Y}=\frac{D_{C}-l_{X 0}}{\tan \theta}-l_{B Y}-\frac{1}{2} \frac{C_{3 X}}{b \beta_{3} f_{C}}
\end{array}
$$

$j_{S}=\frac{D_{C}-l_{X 0}}{\tan \theta}-\frac{D_{B}}{2}-\frac{1}{2} \frac{C_{3 X}}{b \beta_{3} f_{C}} \quad$ (柱端のせん断補強筋は危険断面位置)

\section{試験体の最大耐力時の鉄筋応力（ひずみ度）}

付表 1 最大耐力時の鉄筋の応力

\begin{tabular}{c|c|c|c|c}
\hline 記号 & $\mathrm{J} 1$ [正載荷] & $\mathrm{J} 1$ [負載荷] & $\mathrm{J} 1 \mathrm{~N}$ [正載荷] & $\mathrm{J} 1 \mathrm{~N}$ [負載荷] \\
\hline$T_{B W}$ & $247(1336)$ & $194(1050)$ & $253(1372)$ & $199(1075)$ \\
\hline$T_{B E}$ & $93(506)$ & $-10(-54)$ & $114(617)$ & $15(81)$ \\
\hline$T_{C 1 W}$ & $233(1576)$ & $207(1403)$ & $254(1722)$ & $136(921)$ \\
\hline$T_{C 2 W}$ & $93(1258)$ & $80(1087)$ & $76(1022)$ & $20(271)$ \\
\hline$T_{C 3}$ & $71(966)$ & $89(1205)$ & $63(850)$ & $16(222)$ \\
\hline$T_{C 4}$ & $-86(-582)$ & $21(139)$ & $21(144)$ & $45(302)$ \\
\hline$T_{C I E}$ & $167(1131)$ & $129(872)$ & $90(606)$ & $16(108)$ \\
\hline$T_{C 2 E}$ & $93(1258)$ & $80(1087)$ & $76(1022)$ & $20(271)$ \\
\hline$T_{B}$ & $-35(-187)$ & $252(1365)$ & $52(280)$ & $58(316)$ \\
\hline$T_{S}$ & $24(918)$ & $27(1043)$ & $26(1002)$ & $16(596)$ \\
\hline
\end{tabular}

※ 単位： $\mathrm{kN}$ ，括弧内はひずみ度 $(\mu)$ を示す

\section{記号}

$C_{\square} \quad:$ 図 15 中の口位置のコンクリート応力

$T_{\text {口 }}$ : 図 15 中の口位置の鉄筋応力

$j_{\square} \quad$ : 図 15 中の口位置の鉄筋とその反力を与えるコンクリ

一下の応力重心位置との距離

$V_{S}, V_{C}$ : 梁のせん断力, 柱のせん断力

$N_{C 1}, N_{C 2}$ : 柱の軸力

$D_{B}, D_{C} \quad$ : 梁せい，柱せい

$b \quad$ : 梁幅, 柱幅 (本試験体では共通)

$f_{C} \quad$ : コンクリート圧縮強度

$g_{B} \quad$ : 梁の主筋間距離/梁せい（主筋間距離比）

$g_{C l}:$ 柱の外側主筋間距離/柱せい（主筋間距離比）

$g_{C 2} \quad$ : 柱の内側主筋間距離/柱せい（主筋間距離比）

$l_{B X}, l_{B Y}:$ 点 $\mathrm{O}$ から梁主筋折り曲げ部中央までの $\mathrm{X}, \mathrm{Y}$ 方向距離

$l_{X 0} \quad$ : 点 $\mathrm{O}$ から梁危険断面までの $\mathrm{X}$ 方向距離 $\left(=D_{B} / 2 \times \tan \theta\right)$

[2013 年 2 月 20 日原稿受理 2013 年 4 月 11 日採用決定］ 